\title{
To Surcharge or Not to Surcharge: An Empirical Investigation of ATM Pricing
}

by

\author{
Timothy H. Hannan* \\ Elizabeth K. Kiser* \\ Robin A. Prager* \\ James J. McAndrews**
}

May 24, 2001

* Board of Governors of the Federal Reserve System

** Federal Reserve Bank of New York

The views expressed in this paper are those of the authors and do not necessarily reflect the views of the Board of Governors, the Federal Reserve Bank of New York, or the Federal Reserve System. The authors thank Dean Amel, Mitchell Berlin, Marianne Bitler, Erik Heitfield, Steve Rhoades, Martha Starr-McCluer and participants in the September 2000 Conference of the Federal Reserve System Committee on Financial Structure and Regulation for valuable comments and suggestions. Kevin King provided excellent research assistance. 


\begin{abstract}
$\underline{\text { Abstract }}$
This paper investigates depository institutions' decisions whether or not to impose surcharges (direct usage fees) on non-depositors who use their ATMs. In addition to documenting patterns of surcharging, we examine motives for surcharging, including both direct generation of fee revenue and the potential to attract deposit customers who wish to avoid incurring surcharges at an institution's ATMs. Consistent with expectations, we find that the probability of surcharging increases with both the institution's share of market ATMs and the time since surcharging was first allowed in the state, and decreases with the local ATM density. Further, we find evidence consistent with the use of surcharges to attract deposit customers who are new to the local banking market, but find no evidence that larger banks use surcharges as a means to attract existing customers away from smaller local competitors.
\end{abstract}

JEL: G21, L11 


\section{Introduction}

A vigorous national debate arose in 1996 when the Cirrus and Plus national automated teller machine (ATM) networks decided to allow the owners of ATMs linked to their networks to collect usage fees (surcharges) from ATM users. ${ }^{1}$ Many consumers and consumer interest groups view the imposition of surcharges as unfair because it requires customers to pay for access to their own money. Furthermore, some surcharge opponents worry that large banks with extensive ATM networks may use surcharges as a strategic tool to attract customers away from their smaller competitors. Indeed, some large banks have been known to post messages on their ATM screens advising ATM users that they could avoid paying surcharges at that location if they switched their account to the bank owning the ATM. Meanwhile, industry groups portray surcharges as a fee paid in exchange for a service -- convenient access to funds in a deposit account. They argue that in the absence of surcharges, their own deposit customers subsidize non-depositors' use of their ATMs. Surcharge proponents argue further that surcharges benefit consumers by facilitating the deployment of ATMs in many more locations than would otherwise be profitable. In fact, the number of ATMs deployed at locations other than bank branch offices ("off-premise" ATMs) has increased dramatically in the U.S. since the removal of the Cirrus and Plus surcharge bans (see figure 1).

While participants in this debate have conducted, sponsored, or cited surveys of the frequency and magnitudes of ATM surcharges, there has been no systematic empirical analysis investigating the factors associated with surcharging. This paper attempts to fill that gap by documenting patterns of surcharging and exploring the motives for surcharging, including both

${ }^{1}$ Balto (1996), Horvitz (1980), and Salop (1991) provide useful descriptions of the various viewpoints. 
direct revenue generation and the strategic motive of attracting deposit customers who wish to avoid paying surcharges when using the bank's ATMs.

Our unique data set, which includes information on both ATM surcharges and ATM deployments, allows us to investigate how the prevalence of surcharging varies with ATMowner and market characteristics. We find that the probability of surcharging increases with both the institution's share of market ATMs and the length of the time period since surcharging was first permitted in the state, and decreases with the number of ATMs per square mile in the market. Further, we find evidence consistent with the strategic use of surcharges to attract the deposits of customers who are new to the local market, but find no evidence that banks with large numbers of ATMs (typically large banks) use surcharges as a means to attract existing customers away from smaller competitors.

The remainder of the paper is organized as follows. Section II presents some background information on ATM networks and a brief review of the literature. Section III discusses the incentives of ATM owners to surcharge. Section IV presents the empirical specifications employed and considers the likely impact of various firm and market characteristics on the surcharge decision. Section V describes the data and sample, section VI presents the results of the analysis, and a final section presents conclusions.

\section{Background and Literature Review}

Automated teller machines (ATMs) were introduced in the United States in the late 1960s. Initially, these machines were accessible only to the customers of the bank owning the 
machine. ${ }^{2}$ Banks soon came to realize that the per-transaction cost of providing ATM services declined with the number of transactions, and that the value of an ATM network to customers increased with the number of ATMs in the network. This realization led to the formation of shared ATM networks, which linked together the machines of several banks and allowed customers of a bank to access their accounts from any ATM connected to the shared network. ${ }^{3}$ As of March 2000, there were 273,000 ATMs deployed in the U.S., and virtually all of these machines were connected to at least one regional shared ATM network and to one or both of the two largest national shared ATM networks (Cirrus and Plus). ${ }^{4}$

Network operating rules generally allow the institution deploying a machine used by another bank's customer to be compensated for its costs by collecting a network-determined interchange fee from the customer's bank. The customer's bank is then free to charge the customer a foreign fee for using another bank's ATM. However, prior to April 1, 1996, the operating rules of the Cirrus and Plus national networks prohibited owners of ATMs linked to those networks from imposing direct usage fees or surcharges on other banks' customers who used their ATMs, unless the ATMs were located in a state that had passed a law explicitly overriding the surcharge ban. The Cirrus and Plus networks eliminated this surcharge ban as of April 1, 1996, and the incidence of surcharging began to increase shortly thereafter. Since then,

\footnotetext{
${ }^{2}$ Throughout the paper, the terms "bank," "banking organization" and "banking institution" should be interpreted to include all types of depository institutions (i.e., commercial banks, thrifts and credit unions). In places where we want to distinguish among the types of depository institutions we will use the terms "commercial bank" or "thrift."

${ }^{3}$ Felgran and Ferguson (1986) and McAndrews (1991) provide descriptive overviews of the structure, growth and consolidation of ATM networks in the U.S.

${ }^{4}$ See Bank Network News, August 9, 2000.
} 
the U.S. Congress has held hearings on the surcharge issue, many state legislatures have debated statutory bans on surcharges, and some cities have passed laws to ban surcharges.

The existing literature on ATM networks is fairly limited. Of the previous literature on the subject, the most relevant for our purposes are theoretical contributions by Massoud and Bernhardt (2000) and McAndrews (2001), which we discuss in detail below. Other notable contributions include Saloner and Shepard (1995), Matutes and Padilla (1994), and Prager (2001). Saloner and Shepard test for and find evidence of positive network externalities in the case of ATM networks. Specifically, they report evidence indicating that a bank's date of first adoption of an ATM is decreasing in the number of its branches (a proxy for the number of locations and hence for the network effect) and the value of its deposits (a proxy for the number of users and hence for production scale economies).

Matutes and Padilla address the decision by banks to share their ATM networks, thereby allowing the customers of one bank to use the ATMs of another. They note two opposing effects in the decision to share: The network effect, documented by Saloner and Shepard, makes sharing more attractive to banks, since depositors should be willing to accept lower interest rates on their deposits in order to have access to a larger network. Sharing, however, also makes banks more substitutable from the standpoint of the depositor, since the depositor can seek out higher rates offered by a rival bank and still bank at the most convenient location. The resulting increase in price rivalry may make sharing less attractive to banks. Matutes and Padilla note that surcharging can limit the latter effect and also allow banks to appropriate part of the network externality that they generate for depositors, thus making sharing more attractive.

Prager (2001) considers the effects of ATM surcharges on small banking organizations by comparing the experiences of small banks operating in nine states where surcharging was 
permitted prior to 1995 with the experiences of small banks operating in states where surcharging was not allowed during this period. She finds no evidence that banks in the former group lost market share or experienced declines in profitability relative to banks in the latter group between 1987 and 1995. These findings suggest that surcharges within the range experienced during this period did not induce customers of small banks to shift their deposit accounts to larger banking organizations with more extensive ATM networks.

\section{The Effects of Surcharging on Bank Profits}

ATM surcharges can affect a depository institution's profits through two channels -- a direct channel and an indirect channel. The direct channel refers to the fee revenue generated directly from surcharging, and excludes considerations of any change in deposit relationships that may be induced by surcharging. When an institution imposes a surcharge on non-customers using its ATMs, each non-customer transaction generates revenue for the depository institution equal to the sum of the surcharge (collected from the individual conducting the transaction) and the interchange fee (collected from the individual's bank). In the absence of a surcharge, the institution would receive only the interchange fee. Obviously, the demand for ATM transactions by non-customers should be a decreasing function of the surcharge fee. ${ }^{5}$ Note also that if customer demand for a bank's foreign ATM services is sufficiently elastic, levying a surcharge could induce the number of transactions to fall sharply enough to cause surcharge plus interchange revenue to drop below what interchange revenue would be in the absence of

${ }^{5}$ Consistent with this expectation, both the Congressional Budget Office (1998) and McAndrews (1998) find that the proportion of interchange transactions, defined as those ATM transactions in which a depositor of one bank uses the ATM owned by another party, declined for the first time in 1997, after the widespread adoption of surcharging. 
surcharging. In this case, it may be optimal for a bank not to surcharge at all.

The indirect channel refers to the effect of surcharging on the bank's deposit relationships. Because surcharges are typically imposed only on non-customers using a bank's ATMs, higher surcharges have the potential to attract deposit customers to a bank. That is, a customer who wants to use a particular depository institution's ATMs (perhaps because the institution deploys ATMs in locations that are convenient for that customer) is more likely to open a deposit account with that institution if the institution charges non-customers a high fee to use its ATMs than if the institution charges no fee. To the extent that deposit accounts generate profits for financial institutions, surcharges thus indirectly influence profits.

This unique aspect of surcharging -- the potential to attract deposit customers by charging a higher price to non-customers -- may be an important factor determining the patterns we observe in financial institutions' surcharging behavior. Considering only the direct channel, a depository institution would choose a surcharge that maximized the difference between the revenues and costs associated with ATM transactions. The indirect channel adds another dimension to the surcharge decision. The financial institution must consider not only the effect of its surcharge level on the demand for foreign ATM transactions, but also the effect on the number of customers supplying deposits to the bank.

Massoud and Bernhardt (2000) address the dual effects of ATM surcharging in a theoretical framework. Their spatial model includes a customer preference for ATMs near their home location, as well as a periodic random demand for cash away from home. Knowing banks' surcharge levels and ATM locations, each customer chooses a bank at which to hold a deposit account. Among the predictions relevant to our paper, their model shows that a customer's willingness to pay a surcharge is increasing in the distance between the customer and his or her 
own bank's ATM, and in the cost of traveling a given distance. Massoud and Bernhardt also find that the optimal surcharge is increasing in the bank's ATM share. Furthermore, the equilibrium surcharge in their model is higher when customers choose their bank affiliations endogenously than when the choice of bank does not depend on the surcharge.

McAndrews (2001) examines an alternative spatial model to determine banks' equilibrium choices of foreign fees and surcharges. Customers are assumed to have random itineraries around a circular city, to experience random needs for cash, and to be unaware of the locations of their own bank's ATMs. They do know, however, the number of ATMs operated in the market by their bank, and that those ATMs are distributed according to a uniform distribution. The model's predictions are consistent with those of Massoud and Bernhardt in that the equilibrium surcharge is increasing in the market share of the bank, the cost of travel, and the distance between ATMs. McAndrews also predicts, in a symmetric model, that holding the total number of ATMs in a market constant, an increase in the number of banks operating those ATMs (and hence a reduction in the number of ATMs per bank) will lead to an increase in the equilibrium surcharge. This result is due to an increase in the expected minimum distance a customer would need to travel to use his own bank's ATM. Finally, this model predicts that when newcomers to a market choose a bank based partly on the cost of accessing cash through ATMs, and when the deposit relationship yields future profits for the bank, the surcharge will increase in the number of market newcomers.

Each of these theoretical models relies upon somewhat restrictive assumptions to generate its predictions. For example, the Massoud and Bernhardt model does not allow for varying numbers of banks or ATMs, or for variations in market structure. The McAndrews model, on the other hand, assumes symmetry among banks, or, in the case of asymmetry, only 
two banks in the market. While we do not take either model directly to the data, we draw upon their frameworks and predictions to guide our empirical specification and our interpretation of the coefficient estimates.

\section{Empirical Specifications and the Determinants of ATM Surcharging}

As we discuss in section $\mathrm{V}$ below, the data show little variation in the level of the surcharge across institutions that impose this type of fee. Consequently, in our empirical examination of surcharging behavior, we estimate a probit equation in which the dependent variable $Y$ is equal to 1 if the bank imposes a surcharge on other banks' customers using its ATMs, and zero if it does not. We view the bank's equilibrium surcharge decision as a function of a number of bank, market and political characteristics. Equation (1) is our basic estimating equation,

$$
\operatorname{Pr}(Y=1)=\Phi\left(\beta_{0}+\beta_{1} X_{1}+\beta_{2} X_{2}+\beta_{3} X_{3}\right)
$$

where $M$ is the cumulative normal distribution, $X_{1}, X_{2}$, and $X_{3}$ are vectors of institution,

market and political characteristics, respectively, $\beta_{0}$ is a constant and the $\beta_{i}, i=1,2$, and 3 , are vectors of coefficients.

In our initial specification, we include as right-hand-side variables only those factors that we expect will influence the surcharge decision either solely through the direct profit channel or through both the direct and indirect channels. We then consider two alternative specifications in which we add variables that we expect would influence the profitability of surcharging only through the indirect channel. 
Institution characteristics. The bank characteristics in $\mathrm{X}_{1}$ that we consider potentially relevant to the surcharge decision include the institution's share of ATMs in the local banking market in which it was surveyed, its size, and its charter type (whether it is a commercial bank or a thrift institution).

An institution's share of area ATMs should affect its incentive to surcharge through both the direct and the indirect profit channels. In the case of the direct channel, an institution with a larger share of ATMs can charge non-depositors a higher fee for the use of its ATMs because depositors of other institutions would, on average, have to travel a greater distance to use their own institutions' "free" machines. With nonzero travel costs, this results in a greater demand for use of the ATMs owned by institutions with a large share of area ATMs and a greater likelihood that surcharging will be optimal. Furthermore, owners of multiple ATMs in a geographic market may keep prices higher than if each machine were owned and operated independently, in order to limit competition among their own machines. This within-firm joint pricing of substitute products (i.e., ATMs at different locations) could result in higher surcharges by firms that own large fleets of ATMs. Indirect profit considerations also suggest a positive relationship between ATM share and the surcharge decision, since institutions with large local ATM shares, by surcharging, are more likely to induce customers to establish deposit accounts with them in order to avoid the surcharges. Note that both Massoud and Bernhardt (2000) and McAndrews (2001) predict a positive relationship between ATM share and the level of the optimal surcharge.

Many studies of bank fees have found a positive relationship between fees and the size of the banking institution. ${ }^{6}$ This relationship may reflect customer preferences for characteristics of

\footnotetext{
${ }^{6}$ This result has been documented in the Federal Reserve Board's Annual Report to the Congress on Retail Fees and Services of Depository Institutions, Appendix B.
} 
larger banks or differences in market power that go unmeasured by the researcher. Because of this well-documented relationship, we include a measure of bank size in our surcharge equation as a control variable.

We also include a charter-type indicator in our equation to allow for the possibility that commercial banks and thrift institutions behave differently with regard to surcharging. Such behavioral differences might exist, for example, if these institutions focus on serving different customer bases with different types of products.

Market characteristics. Following the previous literature, we define local banking markets as either Metropolitan Statistical Areas (MSAs) or non-MSA counties. ${ }^{7} \mathrm{X}_{2}$ includes several market characteristics that may influence a bank's surcharge decision through either the direct or the indirect profit channel. These comprise both demographic factors and measures of market structure. The measures of market structure included in our analysis are the concentration of ATM ownership in the local banking market, the physical density of ATMs in the market, and the share of market deposits held by banks with few or no ATMs. Demographic factors considered include population density, income, the age distribution and ethnic composition of the population, the importance of tourism to the local economy, and the rate of population in-migration. We first discuss those market characteristics that are expected to influence the surcharge decision only through the direct channel and then those that are expected to operate through the indirect channel.

The Herfindahl-Hirschman index (HHI), defined as the sum of the squared market shares of all firms in a market, is widely used as a measure of market concentration. Its value (which

\footnotetext{
${ }^{7}$ See for example, Hannan and Berger (1989), Prager and Hannan (1998) and Pilloff and Rhoades (2000).
} 
ranges between zero and one when market shares are expressed as decimals or between 0 and 10,000 when market shares are expressed as percentages) reflects a combination of two features of market structure: the number of firms and the degree of inequality of market shares. To predict the relationship between the ATM HHI (the HHI calculated on the basis of the share of ATMs owned by each firm) and the surcharge level, we consider the effects of both these factors. ${ }^{8}$ First, consider holding the number of machines in the market and the firms' relative market shares fixed, while reducing the number of firms (increasing the $\mathrm{HHI}$ ). In the context of a spatial model (see McAndrews (2001)), this change means that the average customer is more likely to find herself near one of her own bank's ATMs when she experiences a need for cash. In other words, at any point in a market area, a customer's expected distance to her own bank's nearest ATM decreases as the number of firms falls (holding all else constant). This distance effect implies a lower willingness to pay to use a foreign ATM, and a corresponding decrease in the surcharge level that can be supported in the market. Thus, while in many pricing models higher levels of market concentration are associated with higher prices (due to market power effects), in the case of ATM surcharges this relationship may be reversed.

We next consider the effect of an increase in the degree of inequality of ATM market shares on the probability of surcharging, holding constant the number of firms and the number of ATMs in the market. As discussed earlier, we expect the motive to surcharge to increase with the firm's own market share, which we control for separately. Holding the firm's own ATM

\footnotetext{
${ }^{8}$ The ATM HHI equals the sum of squared ATM shares of all firms in the market, including the squared share of the bank whose surcharge we are predicting. Including the bank's own ATM share and ATM HHI, but omitting the squared ATM share, could introduce bias by constraining the squared ATM share and the ATM HHI to have equal effects on the dependent variable. To remove this source of potential bias, we enter the squared ATM share separately in the probit equation.
} 
share constant, it is not clear how the degree of inequality of market shares among other firms in the market will affect the motive to surcharge. As inequality increases, the customers of some banks (those with relatively large ATM shares) will be less willing to incur surcharges, but the customers of other banks (those with relatively small ATM shares) will be more willing to pay surcharges. The net effect on the incentive to surcharge will depend on the number of customers falling into each of these categories. Taking into account the two components of the HHI, and considering both spatial and market power effects, the expected sign of the coefficient on the ATM HHI is ambiguous.

We also consider the relationship between the number of ATMs per square mile in the local market area (ATM density) and the decision to surcharge. This variable is expected to influence the surcharge decision through the direct profit channel. Holding other things fixed, including population density and the concentration of ATM ownership, greater ATM density implies that depositors of other institutions need to travel a shorter distance, on average, to reach their own institutions' ATMs. This, in turn, implies a lower willingness to incur a surcharge to use a foreign ATM. These considerations lead to a negative expected relationship between ATM density and the likelihood of surcharging, as predicted by McAndrews (2001).

Population density is considered a likely determinant of the probability of surcharging, since it provides a measure of the overall size of the potential demand for ATM services, other things held constant. Because this variable reflects the degree of urbanization in a geographic area, it may also serve as a measure of the travel cost necessary for a customer to reach an ATM a given distance away. Both McAndrews (2001) and Massoud and Bernhardt (2000) predict a positive relationship between travel cost and a customer's willingness to incur a surcharge. Thus, interpreting population density as either a measure of potential demand or a measure of 
travel cost leads to the expectation of a positive coefficient.

We also include in our equation market-level measures of average income, the percent of the population age 60 or older, and the percent of the population accounted for by minorities. These variables are included to allow for the possibility that banking behavior and ATM usage vary with these types of demographic characteristics. Income may affect an individual's willingness to incur a surcharge through a wealth effect or through its impact on the individual's opportunity cost of time. Older customers may face greater travel costs than younger customers, increasing their willingness to pay surcharges for convenient access to their deposit accounts; alternatively, they may have a lower opportunity cost of time and therefore be more willing to go out of their way to avoid surcharges. Minority customers may tend to live in areas poorly served by bank branches or ATMs, causing them to face greater travel costs to reach alternative ATMs. ${ }^{9}$ Additionally, cash usage patterns or propensity to use an ATM to obtain cash may vary across demographic groups.

The importance of tourism in the local economy is considered as a potential factor influencing the surcharge decision through the direct profit channel. Tourists are likely to exhibit very inelastic demand for the use of other banks' ATMs, since they are likely to be far away from their own bank's machines when they develop a need for cash, or, if their bank happens to have machines nearby, to be poorly informed about the locations of those ATMs. Thus, banks may be more likely to impose surcharges in markets where tourism is important. We now turn to the market variables we consider to represent the potential strategic

${ }^{9}$ While it has been found that the total number of bank branches available in lowerincome areas is typically low (see, for example, Avery et al. 1997), geographic access to bank branches in minority neighborhoods has, to our knowledge, not been well documented. 
motive for surcharging -- that is, the possibility that banks set surcharges in order to attract deposit customers. We include two variables that we believe represent two possible pools of potential customers: the share of deposits in the market held by banks with few or no ATMs, and the rate of population migration into the market. We include these variables in our second model specification, and interact these variables with an indicator of large ATM share in our third specification.

The share of customers in the market served by banks with no ATMs or a small number of ATMs may influence the probability of surcharging through the indirect profit channel. If banks with large ATM deployments use surcharges as a strategic tool to attract customers away from banks with few ATMs, then the customers of the latter group of banks constitute one pool of potential customers that may be attracted by this strategy. These customers are already affiliated with a bank in the local market, and could potentially be induced to switch their local affiliations. To capture this effect, we create a variable that indicates the aggregate share of market deposits held by "small” banking organizations. We use deposits to proxy customers because we cannot directly observe the number of customers at each institution. We use small bank size as a proxy for operating a small number of ATMs, because we do not have ATM ownership data for all banks in a given market and because institution size and the number of ATMs are highly correlated. ${ }^{10}$ Thus, the larger the share of market deposits held by small banks, the greater the incentive should be for banks with many ATMs to surcharge (if surcharging can

${ }^{10}$ The GAO reports that as of February 1, 1997, the median number of ATMs operated by banks with less than $\$ 1$ billion in assets was 2, while the median for banks with assets between $\$ 1$ billion and $\$ 10$ billion was 45 and the median for banks with assets greater than $\$ 10$ billion was 345. Similar numbers are reported for February 1, 1998. 
indeed induce customers in the local market to change banks). We expect this motive to surcharge to be especially strong for those banks with a large share of market ATMs. Therefore, in our third model, we interact the share of market deposits held by small banking organizations with a dummy variable indicating whether or not the bank being observed owns at least ten percent of market ATMs. If banks with larger ATM market shares use surcharging to attempt to attract deposits away from their small-bank competitors, this interaction variable should have a positive coefficient.

The rate of population migration into the local market area is also expected to influence the profitability of surcharging through the indirect channel. Households tend to switch banks infrequently, with switching often associated with a move from one market to another. ${ }^{11}$ Market newcomers are more likely to shop around for attractive bank prices and services than are residents with existing bank affiliations, and should therefore be more price sensitive than the existing customers of competing depository institutions. Indeed, previous studies have found that market in-migration influences the intensity of competition in deposit markets. ${ }^{12}$ While typically this type of price sensitivity leads to price levels that are more favorable to consumers, it may have the opposite effect in the case of surcharging. Since surcharges are paid by individuals who are not deposit customers of the surcharging bank, a bank may be able to attract new depositors by imposing surcharges at its ATMs. We believe this incentive may be particularly strong when the bank owns a large share of ATMs in the market. Thus, the probability of surcharging is expected to be higher for banks operating in markets with higher

\footnotetext{
${ }^{11}$ See Kiser (2001).

${ }^{12}$ See Sharpe (1997) and Calem and Carlino (1991).
} 
rates of in-migration, especially for banks with large shares of market ATMs. We include the inmigration rate in our second model specification, and include in our third model an interaction term between this variable and the dummy variable indicating whether or not the bank holds at least ten percent of market ATMs. We expect the coefficients on both these variables to be positive.

Political characteristics. Political factors affecting the surcharging decision $\left(\mathrm{X}_{3}\right.$ in equation (1)) include whether or not surcharging was permitted in the state prior to April 1996, and whether or not the state legislature considered anti-surcharge legislation after the removal of the national surcharge bans. Banks located in states where ATM surcharging was permitted prior to April 1996 are expected to have a higher probability of surcharging as of June 1997 than banks located in other states.

Following the 1996 removal of surcharge prohibitions by the national ATM networks, several state legislatures began to consider adopting bills that would ban surcharging at ATMs within their states. Concern about such legislative actions may have influenced some banks' surcharge decisions. Thus, banks located in states where surcharge ban legislation had been introduced before June 1997 are expected to be less likely to surcharge than banks located in states where such legislation had not been introduced.

\section{The Data and Sample}

The data set employed in this study was constructed by combining information from a number of different sources. Information about ATM surcharges was derived from a 1997 telephone survey of retail banking fees and services that was commissioned by the Federal 
Reserve Board, pursuant to its obligation to prepare an annual report to Congress on the cost and availability of retail banking services. ${ }^{13}$ The survey sample included approximately 1000 depository institutions (both commercial banks and thrift institutions). Sampling strata were based on seven geographic regions and five size categories, where size was measured by the total assets of the bank or thrift. A description of the sampling frame is presented in the Appendix.

Each sample institution was assigned to the local banking market in which it was contacted by the survey firm. In most cases, this was the market in which the institution was headquartered. Information about the holdings of ATMs in each of these markets was obtained from a proprietary ATM location and ownership database provided by Cirrus. This database includes only those ATMs linked to the Cirrus national ATM network as of May 1998, or approximately 80 percent of all ATMs in the U.S. at that time. In order to be included in our analysis, banks in the surcharge survey had to meet three criteria: (i) they owned or operated at least one ATM; (ii) they responded to a survey question about ATM surcharges; and (iii) their ATM deployment information was available from the Cirrus database.

Information about which depository institutions served each local banking market was obtained from the Federal Deposit Insurance Corporation's June 1997 Summary of Deposits and the Office of Thrift Supervision's June 1997 Branch Office Survey. Additional information about bank characteristics comes from the 1997 Reports of Condition and Income filed by each institution with the Federal Financial Institutions Examination Council. Demographic information about each market was obtained from the 1990 Census of Population. Information on the importance of tourism in the local market was obtained from the Census Bureau's 1997

\footnotetext{
${ }^{13}$ The data were collected by Moebs Services of Lake Bluff, IL.
} 
County Business Patterns. Data estimating the net inflow of population between April 1996 and April 1997 in each market were obtained from the Internal Revenue Service's Migration Flow Data. Information on state policies regarding ATM surcharging was culled from numerous issues of Bank Network News.

Our data set contains surcharge information for 724 depository institutions, including 512 commercial banks and 212 thrift institutions. Overall, 56 percent of the institutions surcharged as of June 1997. Surcharging institutions comprise 61 percent of the commercial banks and 46 percent of the thrifts in the sample. The mean surcharge for those depository institutions that did surcharge was $\$ 1.13$. The mean among surcharging commercial banks was $\$ 1.15$, while that for surcharging thrift institutions was $\$ 1.05$. Figure 2 illustrates the distribution of surcharge levels across all depository institutions. The most common surcharge level, by far, for those that did surcharge was $\$ 1.00$. A small minority of institutions charged $\$ 1.50$, with the remaining institutions distributed rather sparsely over the range from $\$ 0.25$ to $\$ 4.00$. Given the nature of the surcharge distribution, the empirical analysis in this paper attempts to explain a bank's decision whether or not to surcharge, rather than the choice of surcharge level. Thus, the dependent variable in our analysis is a dummy variable equal to one if the bank imposes a surcharge on other banks' customers using its ATMs, and zero if it does not. ${ }^{14}$

Variable definitions are presented in table 1, and means and standard deviations of the variables used in our analysis are shown in table $2 .^{15}$

${ }^{14}$ We repeated our analysis using the surcharge level as the dependent variable, applying a tobit methodology. The results were quite similar to those reported below.

${ }^{15}$ Note that although we have surcharge data for 724 firms, missing values for other variables lead us to use only 608 observations in our analysis. 


\section{The Results}

Table 3 presents the results of maximum likelihood estimation of equation (1). The lefthand columns present the model that excludes our strategic variables, and the middle and righthand columns show the results for the model that includes the strategic variables alone and the strategic variables interacted with the large-ATM-share indicator, respectively.

Consistent with the predictions of Massoud and Bernhardt (2000) and McAndrews (2001), the coefficient of ATM share is positive and statistically significant in the each of our three models (although the significance level varies across specifications), indicating that, as expected, banks with large shares of market ATMs are more likely to impose surcharges than those with smaller shares. A squared-share term is not significantly different from zero in any model specification.

Institution size is measured as the consolidated banking assets of all subsidiaries of the institution's top holding company if the institution is part of a bank or thrift holding company, and the institution's total assets if it is not part of a holding company. The asset distribution in our sample is quite skewed (as is the case for the population of banks in the U.S.); therefore, we employ the natural logarithm of assets in our equations. The estimated coefficient of $\log$ (assets) is positive in each of the three specifications, but significantly different from zero only in the

first model, providing weak evidence that larger organizations are more likely to surcharge than are smaller ones, all else equal. The estimated coefficient of the dummy variable indicating a thrift institution is negative but statistically insignificant in every model, indicating that, when we control for other relevant factors, thrift institutions are no less likely than commercial banks to impose ATM surcharges on other institutions' customers.

The coefficient of ATM HHI is negative in each model but significant at the 10 percent 
level only in the first. Thus, controlling for the bank's ATM share and other factors, a bank operating in a market with a higher Herfindahl-Hirschman index of concentration of ATM ownership is not more likely, and may be less likely, to impose a surcharge than banks operating in markets with lower levels of ATM concentration. As noted above, with the bank's own ATM share accounted for, this variable may capture (inversely) the distance the typical customer of another institution must travel to use their own institution's ATM. As a consequence, the willingness to pay a surcharge, all else equal, would be lower in more concentrated markets, leading to a lower probability of surcharging.

The coefficient of ATM density is negative, as predicted by McAndrews (2001), and significant at the 5 or 10 percent level in each model. This is another indicator of a distance effect, wherein customers in areas with low ATM densities must, on average, travel farther to use their own institutions' ATMs, thereby increasing their willingness to pay a surcharge.

The coefficient of population density is positive, as expected, but significant at the 10 percent level in only one of our three specifications. The coefficient of per capita income is negative in two of our three models, contrary to our expectations, but is not statistically significant. The percent of the population age 60 or greater, while statistically insignificant in the first regression, is significant at the 5 percent level in each of the models that include the strategic variables. The coefficient of percent minority has a positive and highly significant coefficient in every model specification. These findings indicate that, other things being equal, financial institutions are more likely to impose surcharges in markets where people over the age of 59 or belonging to minority groups comprise a greater share of the population. This may reflect a greater willingness to pay for convenient access to cash among these population groups, perhaps due to higher costs of traveling to avoid surcharges or differences in overall cash usage. 
We employ the ratio of the number of hotel and motel employees in the market to total market population (multiplied by 100) to measure the importance of tourism in the area. The coefficient on this measure is negative, contrary to our expectations, but not statistically significant. Note that our failure to find any evidence of an increased likelihood of surcharging in markets where tourism is important does not necessarily imply that ATM owners do not exploit the inelasticity of tourists' demand for access to cash. It may be the case that surcharges are more common and larger in magnitude at certain specific locations (such as tourist attractions, airports, and train stations), but that this does not affect surcharging behavior at other ATMs owned by the same bank within the same market, and therefore does not show up in our data.

Three explanatory variables are included to capture potentially important regulatory differences that might influence the decision to surcharge. Two variables, Early Liberalization 1 and Early Liberalization 2, indicate whether or not the institution is located in a state that explicitly allowed surcharging within the state prior to the nationwide removal of restrictions in April 1996. The first indicator takes on a value of one if the institution is located in a state that allowed surcharging in 1994 or earlier, and the second indicator is equal to one if liberalization occurred in 1995 or the first quarter of 1996.

The coefficient of the first early liberalization state indicator is large, positive and highly significant in every model. The coefficient of the second early liberalization indicator, though positive in every specification, is considerably smaller in magnitude and only marginally significant in one model. These results indicate that institutions located in states that allowed surcharging in 1994 or earlier were much more likely to impose a surcharge, and that institutions located in states where surcharging was introduced in 1995 or early 1996 were slightly more 
likely to surcharge in 1997 than were institutions in states that did not permit surcharging before April 1996. This finding suggests that there may be some dynamic element to the surcharge decision, with those institutions deriving the greatest benefit from surcharging being the earliest adopters. The coefficient of the surcharge ban indicator, which represents location in a state in which legislation banning surcharges had been introduced before June 1997, is negative, as one would predict, but not statistically significant.

As discussed earlier, we include two "strategic" variables to investigate the role ATM surcharges may play in attracting deposit customers. The first variable, small banks' total deposit share (Small Banks' Share), is calculated as the percentage of total deposits in the market held by institutions with assets less than $\$ 250$ million. The coefficient on Small Banks' Share and the coefficient on the interaction between this variable and Bigshare (a dummy variable equal to one if the bank's share of market ATMs exceeds 10 percent) are both negative, with the former being significant at the 10 percent level in model 2 and both coefficients far from statistical significance in model 3. If banks with large shares of market ATMs used surcharges strategically as a means for attracting existing customers away from smaller local competitors, we would expect to see a positive coefficient on the interaction term. We find no evidence supporting the existence of this particular type of strategic behavior. This finding is consistent with the results of Prager (2001), who finds no evidence that small banks operating in states where surcharging was permitted prior to 1996 suffered losses of deposits or declines in profitability relative to small banks operating in states where surcharging was prohibited during that time period. The finding is also consistent with the documented inertia in customer switching behavior among local banks. Thus, banks with large ATM networks may not find it profitable to surcharge for the purpose of inducing switching by local customers if the likelihood 
that a customer switches banks for any reason is very low.

The coefficient of In-migration Rate, defined as the ratio of the number of new households in the market in 1997 to the total number of market households in 1997 (multiplied by 100), is positive and highly significant in both model specifications in which it appears. This positive coefficient, which is consistent with the predictions of Massoud and Bernhardt (2000) and McAndrews (2001), suggests that banks use the surcharge strategically to provide an incentive for newcomers to establish deposit accounts with the surcharging institution. The coefficient of the interaction between Bigshare and In-migration Rate is positive, consistent with our expectations, but not statistically significant. The strong positive result on market inmigration suggests that banks may be very successful at using the surcharge to attract deposit customers who are new to the market (and unencumbered by switching costs), even if they are not able to induce local market customers to change institutions. This finding indicates that surcharging could make it more difficult for banks with smaller ATM networks to attract customers among market newcomers, leading to a potential decline in their deposit market shares over time.

\section{Conclusion}

In this paper, we have employed data on ATM surcharges levied by individual depository institutions to investigate their decision whether or not to impose a surcharge for the use of their ATMs by non-depositors. In assessing the likely impact of various institution- and marketspecific characteristics on the decision to surcharge, we distinguish between the direct and indirect effects of surcharging on firm profitability. The direct effect focuses on the demand for use of the institution's ATMs by non-depositors, absent considerations of any change in deposit 
relationships that may be induced by surcharging, while the indirect effect concerns the influence of surcharging on the decision by non-depositors to change banks. We have found this simple dichotomy useful in interpreting many of our empirical findings.

We find that the probability of surcharging increases with the institution's share of market ATMs, and decreases with the number of ATMs per square mile, consistent with our expectations. The latter variable relates inversely to the average distance a customer must travel to find an ATM operated by his own bank. We also find that the probability of surcharging is increasing in the proportion of the population age 60 or greater and in the percent of the population of minority ethnicity. We believe these variables relate to the cost of travel, distance to the customer's home bank ATM, or cash usage patterns. As expected, we find that state legislation explicitly permitting surcharging before the Cirrus and Plus networks lifted their bans in 1996 is strongly associated with observed surcharging in 1997.

Further, we find evidence consistent with the strategic use of surcharges to induce customers who are new to the local market to establish deposit relationships with the ATMowning bank. However, we find no evidence that banks with large ATM shares are able to use surcharges successfully as a means to attract existing customers in the local market away from smaller competitors. This suggests that, although small banks with few ATMs are not likely to suffer a substantial loss of customers in the short run as a result of surcharging, they may have difficulty maintaining their deposit market shares over the long run, as market newcomers are attracted to banks with larger ATM shares. It also suggests that surcharges serve not solely as convenience fees for ATMs in high-cost or high-value locations, but also as a strategic tool for raising the costs of access to cash for customers of rival banks. These results are indicative of the important role that spatial networks play in markets for retail deposits. 
Table 1 - Variable Definitions

\begin{tabular}{|c|c|}
\hline Variable & Definition \\
\hline Surcharge Dummy & Dummy variable $=1$ if bank's surcharge $>0$ \\
\hline ATM Share in Market & $\begin{array}{l}\text { Bank's share of all ATMs in the market*, excluding } \\
\text { nondepository institutions }\end{array}$ \\
\hline Bigshare & Dummy variable $=1$ if ATM Share $>10 \%$ \\
\hline Assets & $\begin{array}{l}\text { Consolidated banking assets of all subsidiaries of the } \\
\text { top holding company if the institution is part of a } \\
\text { holding company; the institution's total assets if not } \\
\text { part of a holding company }\end{array}$ \\
\hline Thrift Institution & Dummy variable $=1$ if a thrift institution \\
\hline ATM HHI & $\begin{array}{l}\text { Sum of squared ATM shares in the market, excluding } \\
\text { the shares of nondepository institutions }\end{array}$ \\
\hline ATM Density & $\begin{array}{l}\text { Number of ATMs per square mile in the market, } \\
\text { excluding ATMs of nondepository institutions }\end{array}$ \\
\hline Population Density & Persons per square mile in the market \\
\hline Per Capita Income & Income in the market $(\$ 1000$ s) per capita \\
\hline Percent of Population Age $60+$ & Percentage of persons in the market age 60 or older \\
\hline Percent Minority & $\begin{array}{l}\text { Percentage of persons who identify themselves as } \\
\text { Black, Asian Pacific, Native American or "other" }\end{array}$ \\
\hline Hotel and Motel Employees & $\begin{array}{l}\text { Ratio of number of hotel and motel employees in } \\
\text { market to market population, multiplied by } 100\end{array}$ \\
\hline Small Banks' Share & $\begin{array}{l}\text { Percentage of total deposits in the market held by } \\
\text { institutions with assets less than } \$ 250 \text { million }\end{array}$ \\
\hline In-migration Rate & $\begin{array}{l}\text { Percentage of tax filers new to the market in tax year } \\
1997 \text { since tax year } 1996\end{array}$ \\
\hline Early Liberalization 1 & $\begin{array}{l}\text { Dummy variable }=1 \text { if state passed legislation } \\
\text { overriding Cirrus/Plus surcharge ban by } 1994\end{array}$ \\
\hline Early Liberalization 2 & $\begin{array}{l}\text { Dummy variable }=1 \text { if state passed legislation } \\
\text { overriding Cirrus/Plus surcharge ban 1995-1996(Q1) }\end{array}$ \\
\hline Surcharge Ban Debated in State & $\begin{array}{l}\text { Dummy variable }=1 \text { if a surcharge ban was introduced } \\
\text { in the state legislature before } 1997\end{array}$ \\
\hline
\end{tabular}

*For all relevant variables, "market" refers to the Metropolitan Statistical Area or non-MSA county in which the depository institution was surveyed. 
Table 2 - Descriptive Statistics

\begin{tabular}{l|c|c|c}
\hline \multicolumn{1}{c|}{ Variable } & Mean & $\begin{array}{c}\text { Standard } \\
\text { Deviation }\end{array}$ & Median \\
\hline Surcharge dummy & 0.56 & 0.50 & 1 \\
ATM Share in Market & 13.6 & 18.6 & 5.5 \\
Bigshare (=1 if ATM Share>10\%) & 0.37 & 0.48 & 0 \\
Assets (\$1,000,000) & 14,819 & 40,549 & 487 \\
Thrift Institution & 0.27 & 0.45 & 0 \\
ATM HHI & 0.21 & 0.14 & 0.17 \\
ATM Density & 0.30 & 0.71 & 0.09 \\
Population Density & 680 & 1475 & 205 \\
Per Capita Income (\$1000) & 13.8 & 3.1 & 13.7 \\
Percent of Population Age 60+ & 17.5 & 4.2 & 17.1 \\
Percent Minority & 16.8 & 13.5 & 13.8 \\
Hotel and Motel Employees & 0.52 & 1.91 & 0.27 \\
Small Banks' Share & 23.2 & 25.0 & 12.8 \\
In-migration Rate & 6.8 & 2.4 & 6.6 \\
Early Liberalization 1 & 0.15 & 0.35 & 0 \\
Early Liberalization 2 & 0.08 & 0.27 & 0 \\
Surcharge Ban Debated in State & 0.29 & 0.45 & 0 \\
\hline
\end{tabular}

Sample size $=608$ 
Table 3 - Probit Results

\begin{tabular}{|c|c|c|c|c|c|c|}
\hline \multirow[b]{2}{*}{ Variable } & \multicolumn{2}{|c|}{ No Strategic Variables } & \multicolumn{2}{|c|}{ Strategic Variables } & \multicolumn{2}{|c|}{$\begin{array}{c}\text { Strategic Variables and } \\
\text { Interactions with "Bigshare" }\end{array}$} \\
\hline & $\begin{array}{l}\text { Coefficient } \\
\text { Estimate }\end{array}$ & $\begin{array}{l}\text { Standard } \\
\text { Error }\end{array}$ & $\begin{array}{l}\text { Coefficient } \\
\text { Estimate }\end{array}$ & $\begin{array}{l}\text { Standard } \\
\text { Error }\end{array}$ & $\begin{array}{l}\text { Coefficient } \\
\text { Estimate }\end{array}$ & $\begin{array}{l}\text { Standard } \\
\text { Error }\end{array}$ \\
\hline Intercept & -1.0377 & 0.6355 & $-1.7469 * *$ & 0.7434 & $-1.7506^{* *}$ & 0.7766 \\
\hline ATM Share in Market & $0.0226^{* *}$ & 0.0092 & $0.0246 * * *$ & 0.0095 & $0.0224 *$ & 0.0133 \\
\hline ATM Share Squared & -0.0001 & 0.0001 & -0.0001 & 0.0001 & -0.0001 & 0.0002 \\
\hline Log(Assets) & $0.0540 * *$ & 0.0250 & 0.0431 & 0.0273 & 0.0424 & 0.0274 \\
\hline Thrift Institution & -0.1309 & 0.1320 & -0.1250 & 0.1337 & -0.1274 & 0.1340 \\
\hline ATM HHI & $-1.4705^{*}$ & 0.7969 & -1.2465 & 0.8228 & -1.1972 & 0.8405 \\
\hline ATM Density & $-0.6625^{* *}$ & 0.3202 & $-1.2198 * *$ & 0.6123 & $-1.1958 *$ & 0.6183 \\
\hline Population Density & 0.0002 & 0.0002 & $0.0006^{*}$ & 0.0003 & 0.0005 & 0.0003 \\
\hline Per Capita Income & 0.0020 & 0.0277 & -0.0396 & 0.0300 & -0.0374 & 0.0309 \\
\hline Percent of Population Age 60+ & 0.0118 & 0.0163 & $0.0408 * *$ & 0.0186 & $0.0407 * *$ & 0.0187 \\
\hline Percent Minority & $0.0162 * * *$ & 0.0055 & $0.0191 * * *$ & 0.0058 & $0.0191 * * *$ & 0.0059 \\
\hline Hotel and Motel Employees & -0.0212 & 0.0370 & -0.0661 & 0.0495 & -0.0680 & 0.0487 \\
\hline Early Liberalization 1 & $1.1086^{* * *}$ & 0.2085 & $0.9949 * * *$ & 0.2138 & $0.9979 * * *$ & 0.2143 \\
\hline Early Liberalization 2 & $0.3535^{*}$ & 0.2147 & 0.2354 & 0.2203 & 0.2451 & 0.2241 \\
\hline Surcharge Ban Debated in State & -0.2063 & 0.1382 & -0.1031 & 0.1492 & -0.1005 & 0.1495 \\
\hline Small Banks' Share & & & $-0.0057^{*}$ & 0.0033 & -0.0046 & 0.0063 \\
\hline In-migration Rate & & & $0.1351 * * *$ & 0.0330 & $0.1295^{* * *}$ & 0.0369 \\
\hline Small Banks' Share * Bigshare & & & & & -0.0014 & 0.0065 \\
\hline In-migration Rate $*$ Bigshare & & & & & 0.0116 & 0.0334 \\
\hline
\end{tabular}

Dependent variable $=1$ if surcharge $>0,0$ otherwise. Sample size $=608$. One, two and three asterisks indicate the coefficient is statistically different from zero at the 10, 5 and 1 percent significance levels, respectively, according to a chi-squared test. 


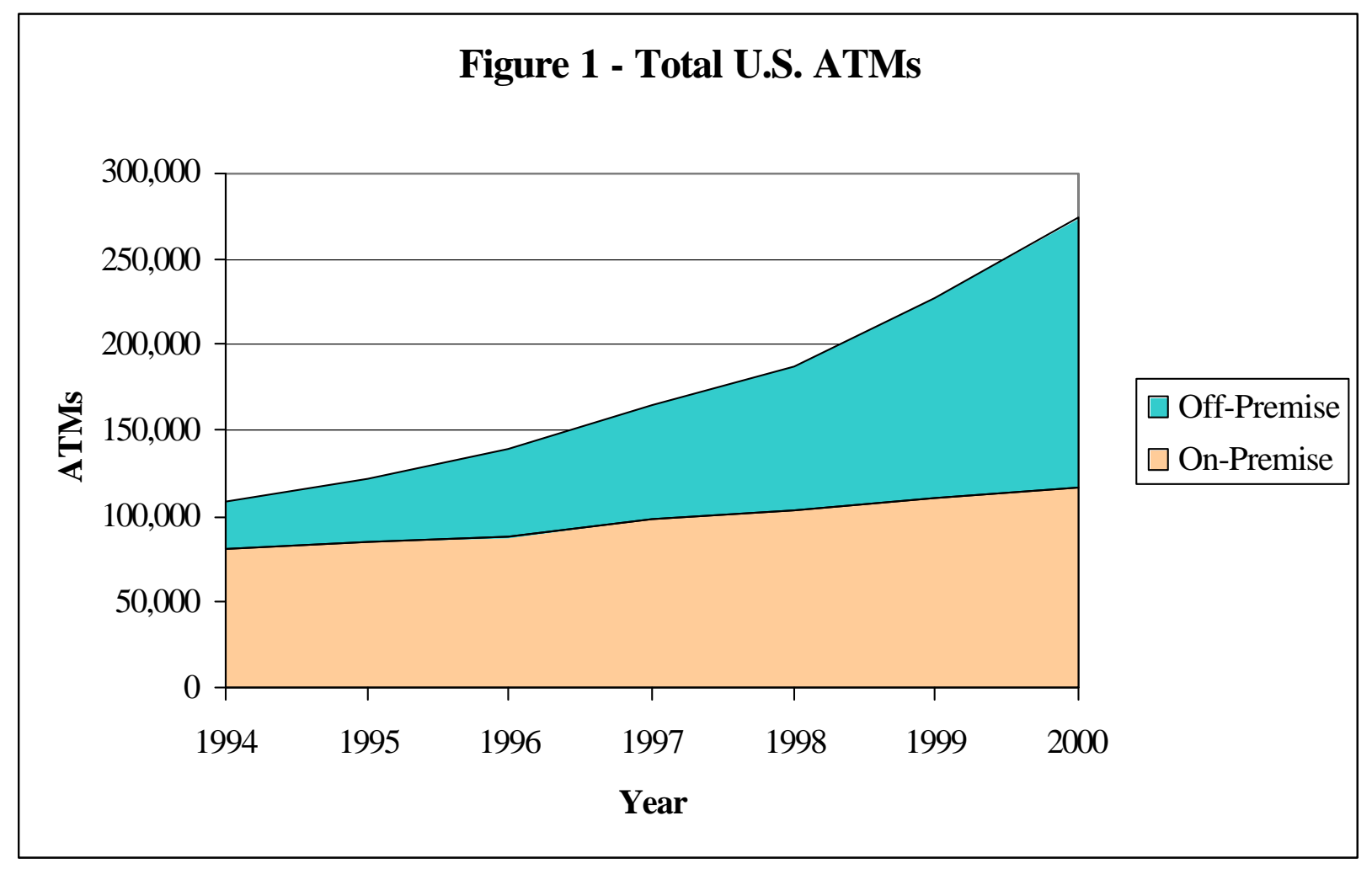

Data source: Bank Network News EFT Data Book 2001. 


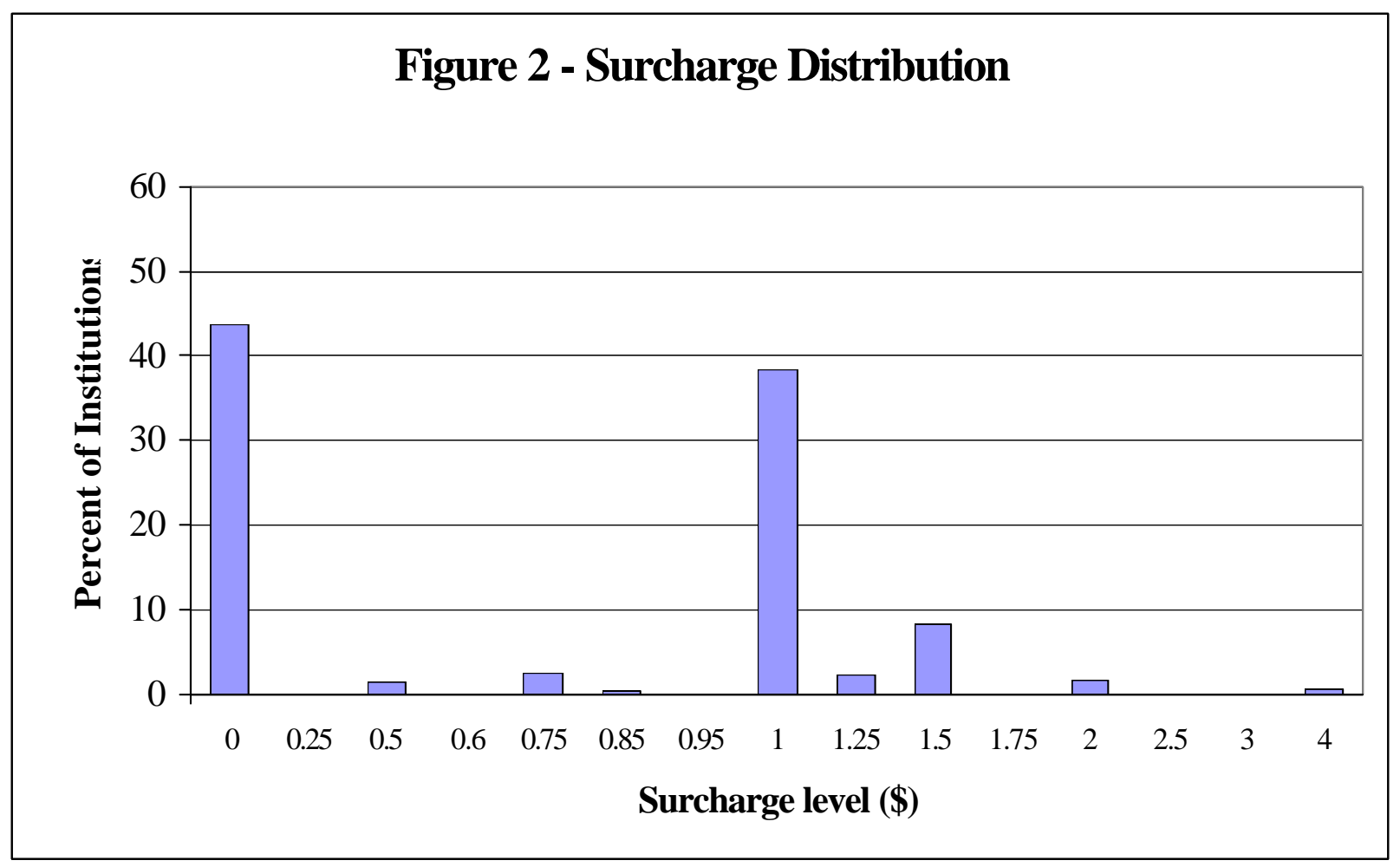

Note: Horizontal axis is not to scale. Sample size $=724$. 


\section{Appendix: Sampling frame of surcharge data}

The surcharge data were collected under contract to the Federal Reserve Board by Moebs Services of Lake Bluff, IL. The data include commercial banks and thrift institutions, and data are collected at the institution level, where institutions are stratified on region and institution size. The regions and size categories are as follows:

$\underline{\text { Region } \quad \text { States/city included }}$

East $\quad$ CT, MA, ME, NH, NJ, NY (excluding NYC)

New York City NYC

South AL, DC, DE, FL, GA, KY, MD, MS, NC, SC, TN, VA, WV

Midwest IA, IL, IN, KS, MI, MN, MO, NE, ND, OH, SD, WI

Southwest $\quad$ AR, LA, OK, TX

West AK, AZ, CO, HI, ID, MT, NM, NV, OR, UT, WA, WY

California CA

$\underline{\text { Size category (total bank or thrift assets) }}$

Under \$25 million

$\$ 25$ - \$100 million

\$250 million - \$1 billion

Over $\$ 1$ billion

The region is that of the headquarters location of the institution. Assets are calculated at the bank or thrift level (and not the holding company, if the institution is part of a holding company). The stratification scheme includes an oversample of institutions in the largest category. From these strata, sampling weights were constructed to allow the data to be scaled to the U.S. population of banks. However, because the distribution of customer accounts and total customer deposits is poorly reflected by the U.S. population of banks, we did not apply the sampling weights in our estimation procedures. 


\section{References}

Avery, Robert B., Raphael W. Bostic, Paul S. Calem, and Glenn B. Canner. "Changes in the Distribution of Banking Offices," Federal Reserve Bulletin 83(9), 1997, pp. 707-25.

Balto, David. “ATM Surcharges: Panacea or Pandora's Box?” The Review of Banking and Financial Services 12(17), October 1996, pp. 169-77.

Calem, Paul, and Gerald Carlino. "The Concentration/Conduct Relationship in Bank Deposit Markets," Review of Economics and Statistics 73, 1991, pp. 268-273.

Congressional Budget Office. "Competition in ATM Markets: Are ATMs Money Machines?" CBO Papers, July 1998.

Federal Reserve Board. Annual Report to Congress on Retail Fees and Services of Depository Institutions, 1995-2000.

Felgran, Steven D. and R.E. Ferguson. "The Evolution of Retail EFT Networks," New England Economic Review, July 1986.

Hannan, Timothy H. and Allen Berger. "The Price-Concentration Relationship in Banking," Review of Economics and Statistics 71, 1989.

Horvitz, Paul M. “ATM Surcharges: Their Effect on Competition and Efficiency," Journal of Retail Banking Services, 18(3), Fall 1988, pp. 57-62

Kiser, Elizabeth K. "Household Switching Behavior at Depository Institutions: Evidence from Survey Data," Federal Reserve Board Working Paper, 2001.

Massoud, Nadia, and Dan Bernhardt. "“Rip-off' ATM Surcharges," University of Illinois at Urbana-Champaign, College of Commerce and Business Administration, Office of Research Working Paper Number 00-0102.

Matutes, Carmen and A. Jorge Padilla. "Shared ATM Networks and Banking Competition," European Economic Review, 38, 1994, pp. 113-38. 
McAndrews, James. "A Model of ATM Pricing: Foreign Fees and Surcharges," Federal Reserve Bank of New York, 2001, available at http://www.ny.frb.org/rmaghome/economist/mcandrews/pubs.html

McAndrews, James. "ATM Surcharges," Current Issues in Economics and Finance, Federal Reserve Bank of New York, 4(4), April 1998.

McAndrews, James. "The Evolution of Shared ATM Networks," Business Review, Federal Reserve Bank of Philadelphia, May/June 1991, pp. 3-16.

Pilloff, Steven J. and Stephen A. Rhoades. "Do Large Diversified Organizations Have Competitive Advantages?" Review of Industrial Organization 16, 2000, pp. 287-302.

Prager, Robin A. "The Effects of ATM Surcharges on Small Banking Organizations," Review of Industrial Organization 18(2), March 2001, pp.161-73.

Prager, Robin A. and Timothy H. Hannan. "Do Substantial Horizontal Mergers Generate Significant Price Effects?" Journal of Industrial Economics, December 1998, pp. 433-52.

Saloner, Garth and Andrea Shepard. "Adoption of Technologies with Network Effects: An Empirical Examination of the Adoption of Automated Teller Machines." Rand Journal of Economics, 26(3), Autumn 1995, pp. 489-501.

Salop, S. "Evaluation of Network Pricing Self-Regulation," in M. Guerin-Calvert and S. Wildman, eds. Electronic Services Networks: A Business and Public Policy Challenge New York, Praeger Publishing, 1991.

Sharpe, Steven. "The Effect of Consumer Switching Costs on Prices: A Theory and its Application to the Bank Deposit Market," Review of Industrial Organization 12(1), 1997, 79-94.

United States General Accounting Office, Automated Teller Machines: Survey Results Indicate Banks' Surcharge Fees Have Increased, GAO/GGD-98-1-101, April 1998. 